\title{
Desaparición, archivo y posverdad: Ayotzinapa en Rafael Lozano-Hemmer
}

\section{Disappearance, archive and post-truth: Ayotzinapa in Rafael Lozano-Hemmer}

\author{
Isis Mariana Yépez Rodríguez \\ Investigadora independiente
}

Fecha de recepción: 9 de noviembre de 2020

Fecha de aceptación: 27 de febrero de 2021

\author{
Anuario del Departamento de Historia y Teoría del Arte \\ vol. 33, 2021, pp. 61-81 \\ ISSN: 1130-5517, eISSN: 2530-3562
}

https://doi.org/10.15366/anuario2021.33.003

\section{RESUMEN}

El presente artículo plantea una revisión de un modo de representación de la desaparición forzada de los 43 estudiantes de la Escuela Normal Rural "Raúl Isidro Burgos" de Ayotzinapa desde el arte contemporáneo a través de la pieza Nivel de confianza (2015) de Rafael Lozano-Hemmer. Las nociones de "archivo", "posverdad" y "capitalismo gore" se vuelven un elemento imprescindible para el análisis de la pieza y la comprensión del acto de desaparición.

\section{PALABRAS CLAVE}

Ayotzinapa. Rafael Lozano-Hemmer. Archivo. Posverdad. Capitalismo gore.

\begin{abstract}
This article proposes a review about a mode of representation of the forced disappearance of the 43 students of the Escuela Normal Rural "Raúl Isidro Burgos" in Ayotzinapa from the perspective of contemporary art through the piece Level of confidence (2015) by Rafael LozanoHemmer. The notions of archive, post-truth and gore capitalism become an essential element for the analysis of the piece and the understanding of the act of disappearance.
\end{abstract}

\section{KEY WORDS}

Ayotzinapa. Rafael Lozano-Hemmer. Archive. Post-truth. Gore capitalism.

\section{Introducción}

El ser de lo que somos es, ante todo, herencia, lo queramos y lo sepamos o no. Jacques Derrida $^{1}$

Todo comienza en la inminencia de una re-aparición, por ejemplo, con la aparición de un espectro o la espera de su aparición ${ }^{2}$. El espectro para Jacques Derrida es aquello que aparece porque ha tenido un fallo,

Nota de la autora: en este artículo se utiliza el masculino como genérico, según las recomendaciones de la RAE, para referirse a personas de distintos géneros.

1 Jacques Derrida, Espectros de Marx. El estado de la deuda, el trabajo de duelo y la nueva internacional (Madrid: Trotta, 1995$), 68$.

2 Derrida, Espectros, 18. 
es una Cosa que nos mira y nos ve no verla. Puede ser una herida de nacimiento, una herida sin fondo, una tragedia irreparable, un fallo de la historia ${ }^{3}$.

Hablar sobre la desaparición forzada en Ayotzinapa es hablar del espectro del que habla Derrida. La desaparición de los 43 estudiantes de Ayotzinapa es un espectro de la historia fallida, algo que nos habla, nos mira y no queremos escucharlo. En ese sentido, como sobrevivientes de esa historia heredada, en cuanto que forma parte de nuestra historia, conlleva comprender que no hay adelante si no trabajamos con lo que pasó, si no estamos abiertos a la deuda por ser sus sobrevivientes, pues "no hay herencia sin la llamada a la responsabilidad. Una herencia es siempre la reafirmación de una deuda"4. Asumir la responsabilidad de la herencia significa hablar de lo fallido, lo no dicho, lo desaparecido que aparece una y otra vez. Honrar nuestra herencia porque fuimos sus sobrevivientes, hacer justicia por lo sucedido.

En el presente artículo expongo la pieza de Nivel de confianza (2015) de Rafael Lozano-Hemmer en la que se visibilizó esa historia fallida. Su foco estuvo en la exigencia de justicia y búsqueda de los estudiantes. Es importante mencionar que las primeras producciones artísticas que se llevaron a cabo por la desaparición de los estudiantes tuvieron mucha mayor presencia en las calles. Fueron el producto de las marchas a nivel nacional convocadas en las primeras semanas después de la desaparición de los 43 estudiantes normalistas de Ayotzinapa.

Sin embargo, en este trabajo no se pretende una revisión de la práctica artística mexicana sobre Ayotzinapa, sino un acercamiento desde la obra de Lozano-Hemmer. Esto permite pensar el caso desde distintas perspectivas teóricas. De este modo se amplía el campo de reflexión frente al caso y se considera cómo han sido pensadas la justicia social, la visibilidad y la exigencia por la verdad desde distintos ángulos de visión y sensibilidades.

Con la revisión de esta obra se pretende realizar una aproximación crítica al caso Ayotzinapa y a las formas de exigencia social que desde el arte contemporáneo es posible articular. Para ello, se considerarán los conceptos de "archivo" y "mal de archivo" de Jacques Derrida y la noción de "posverdad", así como ciertas categorías de análisis que permiten comprender las especificidades geopolíticas desde donde surge el caso de Ayotzinapa: la "necropolítica" desde Achille Mbembe, el "estado de excepción" a partir Giorgio Agamben y el "capitalismo gore" de Sayak Valencia. Esta última noción permitirá comprender y analizar problemáticas surgidas en América Latina con herramientas teóricas latinoamericanas.

Con ello, también se pretende evitar una mirada "desrealizada" frente a la desaparición de los estudiantes. La filósofa Sayak Valencia denominó “desrealización” a una forma de enunciar al Tercer Mundo desde la incomodidad, extranjerizar, o bien, como Judith Butler nombra, "otrorizar". Con ello se cae en una mirada con vetas colonialistas que enuncia la violencia del Tercer Mundo desde el extrañamiento y lo exótico, que atrae la mirada del receptor desde la distancia simbólica y emocional, mostrando a un Tercer Mundo deslegitimado, sin agencia y dotado de una incorrección política. Esto solo genera mecanismos que permiten la insensibilización y legitiman el uso de la violencia en dichos contextos ${ }^{6}$. De forma consecuente con estas ideas y con el hecho de que este trabajo rehúye la espectacularización tanto de la violencia como del otro, no se han seleccionado obras de artistas como Teresa Margolles o Gustavo Monroy, pues a pesar de producir obras de relevancia política y social sobre el contexto mexicano, la forma en que se aproximan a la noción de muerte y desaparición no es la más pertinente para el caso que compete en este trabajo. Más bien, se ha seleccionado la obra de Lozano-Hemmer que, a nuestro juicio, no utiliza la violencia de manera que pueda ser interpretada como objeto de morbo o pantalla, para así evitar que el Primer Mundo voltee una mirada fetichista hacia el Tercer Mundo.

\footnotetext{
${ }^{3}$ Helena Chávez McGregor, seminario “¿Por qué seguir? Cultura y arte a pesar de todo”, MUAC, UNAM, 19 de octubre de 2020 .

${ }^{4}$ Derrida, Espectros, 106.

5 Táctica de guerra para desindentificar al otro como persona e identificarlo como enemigo para poder aniquilarlo.

${ }^{6}$ Sayak Valencia, Capitalismo Gore (Santa Cruz de Tenerife: Melusina, 2010), 167-68.
} 


\section{El caso de Ayotzinapa y la "verdad histórica"}

Y entonces yo llegué al año 1968. O el año 1968 llegó a mí. Yo ahora podría decir que lo presentí, que sentí su olor en los bares, en febrero o en marzo del 68, pero antes de que el año 68 se convirtiera realmente en el año 68. Ay, me da risa recordarlo. ¡Me dan ganas de llorar! ¿Estoy llorando? Yo lo vi todo y al mismo tiempo yo no vi nada. ¿Se entiende? Yo estaba en la facultad cuando el ejército violó la autonomía y entró en el campus a detener o a matar a todo el mundo. No. En la universidad no hubo muchos muertos. Fue en Tlatelolco. ¡Ese nombre que quede en nuestra memoria para siempre!?.

El movimiento estudiantil mexicano de 1968 fue un movimiento formado no solo por los reclamos estudiantiles, sino que incluía muchas otras demandas. La motivación del movimiento comenzó a ser cada vez más profunda y exigía el fin de la represión, de la corrupción y de la inequidad social. Sin embargo, en Tlatelolco, en el centro de la Ciudad de México, dicho movimiento se disolvió a causa de la masacre de miles de personas en la Plaza de las Tres Culturas por parte de militares y oficiales vestidos de civiles. Cada octubre se realiza una marcha en todo el país para recordar que siguen sin esclarecerse los hechos y para evitar que se vuelva a cometer un acto como ese en contra de la población estudiantil, pues "el 2 de octubre, no se olvida".

Cuarenta y seis años después, en 2014, un grupo de estudiantes de la Escuela Normal de Ayotzinapa, Guerrero, salió en autobuses hacia la Ciudad de México para unirse a la marcha del 2 de octubre. Sin embargo, 43 de esos estudiantes nunca regresaron a sus hogares. La versión oficial de lo sucedido fue conocida como la "verdad histórica", nombrada así por el entonces Procurador General de Justicia, Jesús Murillo Karam y el presidente en turno Enrique Peña Nieto. Karam afirmó que esta estaba sustentada en una investigación exhaustiva, profunda, seria y con resultados científicos, basada en análisis de ADN, peritajes y declaraciones como la de Felipe Rodríguez Salgado, supuesto miembro de Guerreros Unidos ${ }^{8}$, que confesó su participación en lo ocurrido. Otros testimonios, además, señalaron a Salgado como líder y responsable de conducir a los estudiantes al basurero de Cocula, interrogarlos, dar la orden de ejecutarlos e incinerarlos ${ }^{9}$. Con estas declaraciones, Karam sacó la siguiente conclusión: los estudiantes fueron confundidos con el grupo antagónico de Guerrero Unidos, Los Rojos. Esta fue la razón por la que los atacaron.

Las razones de la desaparición de los estudiantes sigue siendo una incógnita. Lo que sí se sabe es que los estudiantes se encontraban "boteando" y tomaron cinco autobuses de la Central de Autobuses de Iguala. Algunas hipótesis, como la del Grupo Interdisciplinario de Expertos Independientes (GIEI), apuntan a que uno de los autobuses donde viajaban los estudiantes podría haber tenido trasiego de drogas. Una de las evidencias es la toma del llamado "quinto autobús" y el hecho de que sus ocupantes (estudiantes de Ayotzinapa que sobrevivieron) no fueron atacados. Sin embargo, la PGR ignoró estos datos.

Por su parte, la Comisión Nacional de los Derechos Humanos (CNDH) en México consideró inverosímil la tesis de que solo una persona estuviera a cargo de lo sucedido, pues una particularidad de la delincuencia organizada es que cada uno de sus integrantes conoce solo un segmento de la información ${ }^{10}$.

El manejo de información sobre la "verdad" llegó a ser denigrante para las víctimas al grado de culpar a los estudiantes de ser parte del crimen organizado o tener algún vínculo con el narcotráfico con el fin de

\footnotetext{
7 Roberto Bolaño, Los detectives salvajes (Barcelona: Anagrama, 1998), 192.

8 Grupo de crimen organizado que salió de la Organización Beltrán Leyva. Opera principalmente en los estados de Morelos y Guerrero. El grupo se conoce por realizar secuestros, extorsiones y tráfico de drogas. En "Guerreros Unidos", InSight Crime, consultado el 22 de noviembre de 2015, https://es.insightcrime.org/mexico-crimen-organizado/guerreros-unidos/.

9 El Universal, "Caso Ayotzinapa. Esta es la verdad histórica del exprocurador Jesús Murillo Karam”, El Universal, 25 de septiembre de 2019, https://www.eluniversal.com.mx/nacion/caso-ayotzinapa-esta-es-la-verdad-historica-del-exprocurador-jesusmurillo-karam.

${ }^{10}$ Comisión Nacional de los Derechos Humanos, Recomendación No. 15VG/2018 “Caso Iguala” (México: CNDH, 2018), 744, https://www.cndh.org.mx/sites/all/doc/Recomendaciones/ViolacionesGraves/RecVG_015.pdf.
} 
generar legitimidad del Estado frente a lo ocurrido ${ }^{11}$. Cuando se habla de alguna relación con el narcotráfico en México, cualquier acto de violencia parece estar justificado. Frente a dichos argumentos, el GIEI afirmó no haber encontrado evidencia de tales acusaciones. Además, las autoridades de Iguala sabían que los jóvenes se dirigían a la marcha del 2 de octubre ${ }^{12}$.

En el proceso de búsqueda se hallaron innumerables fosas comunes. En consecuencia, el Centro de Derechos Humanos de Tlachinollán, junto con los familiares de los desaparecidos, solicitó la ayuda del Equipo Argentino de Antropología Forense (EAAF), reconocido por su labor de identificación de personas desparecidas en la dictadura argentina ${ }^{13}$.

En colaboración con el EAAF y el Centro de Derechos Humanos Miguel Agustín Pro Juárez (Centro Podh), se comisionó a Forensic Architecture ${ }^{14}$ a construir una plataforma cartográfica que trazaba y examinaba las diferentes posibles narrativas de lo acontecido. El proyecto tuvo como objetivo reconstruir la totalidad de los eventos conocidos y proporcionar una herramienta forense para futuras investigaciones del caso. Dicha plataforma ${ }^{15}$, así como un mural titulado Los senderos de Iguala que se bifurcan, que mostraba las posibilidades de lectura de los eventos acontecidos, se exhibieron en la exposición llevada a cabo en 2017 en el MUAC con el nombre Forensic Architecture: Hacia una estética investigativa.

Sin embargo, en cuanto al proceso de investigación forense in situ, al EAAF no se le permitió acceder a las fosas clandestinas, ni recabar muestras. El material estudiado era entregado por las autoridades mexicanas con los informes de los peritajes ya realizados. El único peritaje que realizó el EAAF fue en el basurero de Cocula, con el que concluyeron que no había evidencia científica de un incendio de tal magnitud y duración para calcinar 43 cuerpos, por lo que la "verdad histórica" no se sostenía.

A su vez, la Comisión Interamericana de Derechos Humanos (CIDH) junto con el GIEI señalaron que persistió una investigación fragmentada, incompleta y sin una directriz clara, aunado a la falta de atención a los familiares, la ausencia de detenciones por desaparición forzada y detenciones de actores estatales ${ }^{16}$.

En estos hechos hubo participación directa de dos cuerpos de policía municipal de Iguala y Cocula y probable agentes de otros cuerpos de seguridad de la zona. La detención de los autobuses donde viajaban los normalistas por parte de estos agentes muestra la intención de no dejarlos salir de Iguala. El único cuerpo encontrado fue de Julio César Mondragón, quien fue brutalmente torturado, por lo que se cree que pudo haber sucedido algo muy similar con los demás estudiantes ${ }^{17}$.

A los seis años de lo acontecido se liberaron a 77 de los 142 implicados en el caso, incluyendo a Salgado, por falta de pruebas. Lo que queda claro es que asesinaron a seis personas, que hubo más de 42 heridos (cinco de gravedad) y sigue habiendo 43 desaparecidos ${ }^{18}$. Carlos Beristain, ex integrante del

\footnotetext{
${ }^{11}$ Alejandro Valencia Villa et al., Informe Ayotzinapa (México: GIEI, 2015), 333-34, https://centroprodh.org.mx/2017/12/11/ informe-giei-ayotzinapa/

12 Valencia Villa et al., Informe Ayotzinapa, 13, 45.

13 Natalia Elizabeth Talavera Baby, "Soberanía, crueldad y biopolítica. Apuntes sobre el caso Ayotzinapa", Las Torres de Luca. Revista internacional de filosofía política 7 (2015): 23-48.

${ }^{14}$ Forensic Architecture es una agencia de investigación fundada en 2010 por el arquitecto y activista israelí Eyal Weizman. Junto con un grupo de arquitectos, artistas, cineastas, periodistas, científicos y abogados, actúan de forma independiente o a petición de juristas internacionales y ONGs. Su labor como agencia no busca resolver los casos, sino enfrentar las preguntas políticas e históricas que enmarcan a cada proyecto. Eyal Weizman, "Ayotzinapa como investigación multidisciplinaria. Entrevista con Forensic Architecture", entrevistado por Gabrielle Vinós, Revista Código 26 (2017), último acceso 26 de febrero de 2021, https:// revistacodigo.com/arquitectura/entrevista-forensic-architecture-la-desaparicion-narrativa/

${ }^{15}$ La plataforma se puede consultar en línea: http://www.plataforma-ayotzinapa.org/, último acceso 26 de febrero de 2021.

${ }^{16}$ Alejandro Valencia Villa et al., Informe Ayotzinapa. Resumen (México: GIEI, s/f), 28, http://www.oas.org/es/cidh/actividades/ giei/ResumenEjecutivo-GIEI.pdf

17 Alejandro Valencia Villa et al., Informe Ayotzinapa II (México: GIEI, 2016), 15-17, http://www.oas.org/es/cidh/actividades/ giei/GIEI-InformeAyotzinapa2.pdf

18 Plataforma Ayotzinapa, "Una cartografía de la violencia", Sobre el proyecto, consultado el 11 de noviembre de 2019 , http://www.plataforma-ayotzinapa.org/.
} 
GIEI, expresó que cuando ellos comenzaron el proceso de la investigación en Iguala ya había muchas pruebas, era un expediente enorme de peritajes y estudios. Sin embargo, las conclusiones eran especulativas, había un salto que hacía pensar que alguien estaba diciendo lo que se debía concluir. El hecho de hablar de resultados científicos para justificar la "verdad histórica" es algo que se fue haciendo para dar veracidad al caso y mostrar los avances de la investigación. Sin embargo, las pruebas tejieron conclusiones por medio de un uso selectivo de hechos que apoyaban una posición del Estado y rechazaban por completo los hechos que no lo hacían ${ }^{19}$.

En consecuencia, la "verdad histórica" fue parte de la maquinación de una idea de "verdad" sin interés por encontrar las causas ni llevar una investigación certera de lo acontecido. Como en el 68, se mostró un Estado que perdió el control sobre la violencia estatal, la fuerza se le escapó de las manos y con ella su credibilidad frente a la población ${ }^{20}$.

\section{Verdad y posverdad}

En 2016 los diccionarios de Oxford eligieron la palabra "posverdad" (post-truth) como la palabra del año después de que Donald Trump ganara las elecciones presidenciales de Estados Unidos y se consiguiera el "sí" en el referéndum del Brexit. Según la definición de este diccionario, la "posverdad" se relaciona con todas aquellas circunstancias en las que las personas responden más de acuerdo a las emociones y creencias que a los hechos. Cabe mencionar que el "pos" no se relaciona con "dejar atrás la verdad", más bien, pretende indicar que la "verdad" es irrelevante ${ }^{21}$.

A la "posverdad" no le importa la "verdad", simplemente pretende reunir ciertos elementos fácticos de forma creíble. Según el investigador Lee McIntyre, la "posverdad" equivale a una forma de supremacía ideológica por medio de la cual se trata de obligar a alguien a que crea algo independientemente de las evidencias que haya al respecto ${ }^{22}$.

La diferencia que tiene la "posverdad" con la mentira es que esta última sí se contrapone a la "verdad". El que miente desafía los enunciados de "verdad", se opone a ellos. Pero el bullshiter los ignora de modo absoluto. No tiene la vista puesta en los hechos a menos que estos puedan ser pertinentes para sus propios intereses ${ }^{23}$.

Un ejemplo de cómo se tradujo la "posverdad" en el caso Ayotzinapa fue el comportamiento del exprocurador Murillo Karam, cuyo objetivo parecía ser dar "carpetazo" al caso a toda costa. Con la "verdad histórica" se buscó construir un discurso que acomodaba los hechos a una narrativa específica, con un interés mínimo por esclarecer la "verdad”. Así, Karam dio a conocer la detención de Salgado y afirmó que, tras 386 declaraciones, "esta es la verdad histórica: los normalistas fueron calcinados, están muertos"24.

\footnotetext{
19 Carlos Beristain "De la verdad incómoda a la mentira insostenible: Carlos Beristain, a cinco años de Ayotzinapa", entrevistado por Heriberto Paredes, Marina Azahua y Timo Dorsch, Este País, 19 de septiembre de 2019, https://estepais.com/tendencias___ opiniones/sociedad/de-la-verdad-incomoda-a-la-mentira-insostenible-carlos-beristain-a-cinco-anos-de-ayotzinapa/. Lee McIntyre, Posverdad (Madrid: Cátedra, 2018), 60.

${ }^{20}$ Sergio Aguayo, "Mexico in helplessness, from Tlatelolco to Ayotzinapa", entrevistado por José Zepeda, Open Democracy, 16 de noviembre de 2016, https:/www.opendemocracy.net/en/democraciaabierta/mexico-in-helplessness-from-tlatelolco-toayotzinapa/

${ }^{21}$ Oxford dictionaries, s.v. "post-truth", consultado el 10 de octubre de 2019, https://www.oxfordlearnersdictionaries.com/ definition/english/post-truth

22 McIntyre, Posverdad, 34, 40-41.

${ }^{23}$ Harry Frankfurt, On Bullshit (Princeton N.J: Princeton University Press, 2005), 17-18, http://www2.csudh.edu/ ccauthen/576f12/frankfurt_harry___on_bullshit.pdf

24 Jenaro Villamil, "Ayotzinapa, la mentira histórica al desnudo", Proceso, agosto de 2015, https://www.proceso.com. $\mathrm{mx} / 413220$ /ayotzinapa-la-mentira-historica-al-desnudo
} 
Otro ejemplo de cómo la "verdad histórica" se construyó en prácticas asociadas a la "posverdad" tiene que ver con la detención del "quinto acusado". Beristain afirma que habían explicado al fiscal las razones por las cuales la "verdad histórica" no se sostenía, le revelaron los vacíos que había con los testigos y que las versiones no cuadraban. Después de ello detuvieron y tomaron declaración al "Duva". Beristain afirmó que la declaración de este llenaba los huecos que faltaban y el fiscal le dijo: "ahora sí cuadra la versión"25; de manera que se construyeron evidencias para acomodar el caso a sus propósitos y argumentar la "verdad histórica". La estrategia desarrollada en el proceso de construcción de pruebas, que después formarían parte de la versión oficial, se asemeja frecuentemente a decir bullshits. En este ámbito no importa la "verdad" siempre y cuando lo que se diga funcione ${ }^{26}$.

Una ola de indignación por parte de la población se propagó rápidamente por los resultados de la investigación. Pero no hubo exigencias de medidas claras, como la interrogación de militares y policías, ni se hizo presión por la desaparición de ciertas pruebas. No se exigió la independencia de los servicios periciales, ni evitar la fragmentación del caso en fiscalías distintas que generan confusión y dispersión de pruebas ${ }^{27}$. Aunque no se creyó en la "verdad histórica", se dio por hecha, sin profundizar en los vacíos que estaban a la vista de todos. La población se dejó cegar por el velo de la "verdad histórica" y por la emocionalidad de la indignación de las noticias. Solo eso.

Esto es solo un indicador de la relación de nuestra era con la "verdad" y el lugar contemporáneo en la configuración de nuestro sentido de la realidad. Como bien expone Beristain, hay que ver el proceso de la masacre, hay que ver el proceso de la impunidad. Lo que se logró con la exigencia de la sociedad civil fue solo el eterno retorno a la indignación y la rabia pero, como ya se ha señalado, sin exigencias específicas que cambiaran el proceso por el cual la legalidad en México está orientada a generar impunidad $^{28}$.

\section{Capitalismo gore y estado de excepción}

Ayotzinapa parece ser, lamentablemente, un ejemplo de "estado de excepción", donde los derechos individuales se disminuyeron, reemplazaron y rechazaron. El "estado de excepción" sucede con la supresión de las leyes dentro de un estado de emergencia o de crisis. Los derechos se ven disminuidos o rechazados por mandato del soberano, ubicándose en una zona de indistinción entre un afuera y un adentro de la ley ${ }^{29}$. Uno de los grandes problemas del "estado de excepción" es que puede convertirse en un estado prolongado de ser, en una norma; donde el objeto de la "biopolítica" pase a ser la vida nuda de la que habla Agamben, una vida que se encuentra en el umbral entre lo humano y lo no humano. En el contexto mexicano, la criminalidad se centra en un terreno donde el "estado de excepción" es la norma y en donde el soberano puede matar en cualquier momento, de todas las formas posibles.

La "biopolítica" para Michel Foucault implica una somatocracia. Foucault pone como ejemplo las normas que deben seguir los cuerpos en una epidemia, instalando mecanismos de seguridad y gobernabilidad para optimizar un estado de vida y así "hacer vivir y dejar morir" 30 . Achille Mbembe considera que la "biopolítica" es insuficiente para evidenciar las formas contemporáneas de sumisión de la vida

25 Beristain, "De la verdad".

26 McIntyre, Posverdad, 15.

27 Beristain, "De la verdad".

28 Beristain, "De la verdad".

29 Achille Mbembe, Necropolítica. Sobre el gobierno privado indirecto, traducción de Elisabeth Falomir Archambault (Santa Cruz de Tenerife: Melusina, 2011), 40; Laura Quintana Porras, "De la Nuda Vida a la 'Forma-de-vida'. Pensar la política con Agamben desde y más allá del paradigma del biopoder", Argumentos 19, n. 52 (2006): 47; Giorgio Agamben, Homo Sacer. El poder soberano y la vida nuda, traducción de Antonio Gimeno Cusspinera (Valencia: Pre-textos, 1998), 34.

${ }^{30}$ Michel Foucault, Defender la sociedad. Curso en el Collège de France (1975-1976) (Buenos Aires: FCE, 2001$), 223$. 
al poder de la muerte ${ }^{31}$, por lo que propone la "necropolítica" como la expresión final de la "soberanía" que reside en "el poder y la capacidad de decidir quién puede vivir y quién debe morir. Hacer morir o dejar vivir"32. La diferencia entre la operación "biopolítica" y la "necropolítica" reside en la activación del racismo.

El racismo en la "biopolítica" opera como dispositivo estatal sobre las poblaciones indeseadas al interior de las fronteras europeas; poblaciones que "no sirven" para el trabajo productivo, el desarrollo económico y la modernización. En la necropolítica, el racismo procedente de la negación racista de todo punto en común del conquistador hacia el indígena. El racismo requiere de una lectura particular en el caso de México pues la "soberanía" no es aplicada de la misma manera que en los estados europeos, ya que las formas coloniales de "soberanía" han practicado una forma de violencia más excesiva ${ }^{33}$. Desde esta lógica, los cuerpos de los estudiantes de Ayotzinapa pasaron a ser fácilmente "torturables" y "desechables" al ser cuerpos morenos y pobres. Se edificaron como sujetos "exterminables" y se les convirtió en un "ser matable" 34 .

La filósofa mexicana Sayak Valencia sugiere que la "necropolítica", en el caso de México, está encarnada en las mafias y criminales que forman parte de "capitalismo gore". Este es definido por Valencia como el lado B del capitalismo, donde no se viven las "virtudes" del capitalismo. Más bien, se comercia desde el necropoder con el proceso de dar muerte ${ }^{35}$.

Desde esta mirada, el "capitalismo gore" inició su andadura en el "estado de excepción" como un estado prolongado de ser. A la vez, el Estado y los "sujetos endragos" que son quienes, según Valencia, "deciden hacer uso de la violencia como herramienta de empoderamiento y de adquisición del capital" 36 , trabajan en paralelo y se disputan el poder de oprimir. Incluso pueden llegar a difuminarse sus fronteras y a entrecruzarse sus acciones. Por lo tanto, no existe un único Estado. Valencia expresa que existen al menos dos: el de la insurgencia y el legal. En este sentido, se hace de la gobernabilidad un monopolio ${ }^{37}$. En el caso de Ayotzinapa, esta reflexión coincide con la del investigador y profesor del Colegio de México, Sergio Aguayo, que parte de esta premisa: Tlatelolco y Ayotzinapa representan dos expresiones de un mismo fenómeno. Como ya se ha señalado, ambos suponen la pérdida del control por parte del gobierno mexicano. En el 68 el Estado mexicano experimentó cómo el control de la fuerza se le escapaba de las manos. Con Ayotzinapa, el control fue capturado por el crimen organizado y otras instancias políticas y estatales. Al final, concluye Aguayo, el problema es el mismo: un Estado que no controla la violencia tampoco puede proteger a sus ciudadanos ${ }^{38}$.

Entonces, el "estado de excepción" y de crisis se afirma con un Estado ausente, que deja gran parte del territorio al crimen organizado. La población se ve embestida por grupos interesados en hacer dinero y ejercer su poder sobre la vida y la muerte. Aunque la violencia del "capitalismo gore" nos traspasa de alguna u otra manera a todos, es importante recordar que la distribución de la violencia obedece a cuestiones geopolíticas. No es casualidad que estudiantes pertenecientes a una comunidad del estado de Guerrero en México sufrieran las consecuencias de este capitalismo pues forman parte de lo que Valencia designa como "devenir minoritario". Esto son todos aquellos cuerpos en quienes recae toda la violencia explícita de un

\footnotetext{
31 Mbembe, Necropolítica, 75.

${ }^{32}$ Mbembe, Necropolítica, 19.

33 Santiago Castro-Gómez, "Michel Foucault y la colonialidad de poder", Tabula Rasa 6 (2007): 157-58; Mbembe, Necropolitica, 36-37, 39-40, https://doi.org/10.25058/20112742.290.

${ }_{34}$ Maciek Wisniewski, “Ayotzinapa/Iguala: lectura desde necropolitica”, La Jornada, 18 de octubre de 2019, https://www. jornada.com.mx/2019/10/18/opinion/025a2pol; Valencia, Capitalismo Gore, 208.

35 Valencia, Capitalismo Gore, 143, 147.

36 Valencia, Capitalismo Gore, 90.

37 Valencia, Capitalismo Gore, 18-19, 144, 207.

38 Aguayo, "Mexico in helplessness".
} 
país donde impera el "capitalismo gore"39. La tecnología del racismo se aplica para "hacer morir" a estos grupos que, por provenir de un contexto rural, con "poco desarrollo" económico y lazos identitarios distintos son considerados como "obstáculos" ante el avance de la "modernización".

En consecuencia, los estudiantes de Ayotzinapa fueron víctimas de las necroprácticas con las que los "sujetos endriagos" vulneran corporalmente a sus enemigos. Esto quedó muy claro en las declaraciones de los interrogados, quienes "justificaron" las acciones afirmando que habían confundido los autobuses de los estudiantes con los de un grupo de narcotraficantes enemigo. Independientemente de que eso sea cierto o no, lleva a reflexionar sobre cómo los cuerpos que recurrentemente son tocados de las maneras más injustas en México son los de las mujeres, las comunidades indígenas y los estudiantes. Parece que el "devenir minoritario" en México está conformado por estas poblaciones. Con esta investigación se pretende visibilizar, revisar e indagar un discurso que permea las realidades actuales y llega, de esta manera, a modo de exigencia, al arte contemporáneo.

\section{Biométrica: Rafael Lozano-Hemmer | Nivel de confianza / Level of confidence}

Rafael Lozano-Hemmer nació en la Ciudad de México en 1967. Dado que es mexico-canadiense, se mueve principalmente en estos dos contextos. Su producción artística se mueve entre la arquitectura relacional y el performance, ya que su obra se caracteriza por crear proyectos desde la estética relacional con el objeto de involucrar la participación del público y el trabajo artístico. Por tanto, sus proyectos comienzan a existir en el momento en que las personas participan y activan la obra. Su trabajo combina la lógica digital, la base de datos y el algoritmo. El artista parte del supuesto de que la tecnología, más que una herramienta, es una forma inevitable de determinación de subjetividad y sociabilidad que incluye, por tanto, el juego con los sentidos.

Entre sus obras se encuentra $\operatorname{Voz}$ Alta $(2008)^{40}$, una instalación pública que actúa como un memorial comisionado por el Centro Cultural Tlatelolco de la UNAM por el 40 aniversario de la masacre de los estudiantes en Tlatelolco en 1968. Esta obra relacional consistió en un megáfono dispuesto en el lugar donde sucedió la masacre que potenciaba las voces de quienes lo utilizaban y, a su vez, transformaba dichas voces en luces que iluminan gran parte del centro de la Ciudad de México. Asimsimo, Radio UNAM retransmitía las voces para quienes quisieran sintonizarlas en cualquier parte de la ciudad. La participación fue sin censura alguna y sin tiempo límite. Cuando no había participación alguna, se retransmitían archivos de grabaciones del 68. Así, la participación activa del público se entremezclaba con memorias del trágico evento. Por medio del megáfono se compartieron historias de habitantes de Tlatelolco que sobrevivieron a la masacre; así también, la gente compartió nuevos significados sobre el pasado, comparativas con el presente, rap, poesía e incluso hubo propuestas de matrimonio. Esta obra también se vivió como un acto político, de recuperación de la memoria oral y, de esta manera, se puso al arte al servicio de la gente.

Por su parte, la obra que nos atañe, Nivel de confianza, se expuso como parte de la exposición Rafael Lozano-Hemmer, Pseudomatismos (2015) en el MUAC de la Ciudad de México. También se mostró en varias universidades, galerías y centros culturales en México, Canadá, Reino Unido, España y Argentina, entre otros.

Para dicha obra, el artista utilizó algoritmos de vigilancia biométrica de reconocimiento facial empleados habitualmente para buscar sospechosos; solo que, en su caso, los usó para buscar a los desaparecidos ${ }^{41}$.

\footnotetext{
39 Valencia, Capitalismo Gore, 19.

40 Véase https://www.lozano-hemmer.com/voz_alta.php, último acceso 26 de febrero de 2021.

41 Rafael Lozano-Hemmer, "Nivel de confianza, de Rafael Lozano-Hemmer", entrevistado por Revista Código, Revista Código, 9 de abril de 2015, https:/revistacodigo.com/arte/nivel-de-confianza-de-rafael-lozano-hemmer-ayotzinapa/
} 
La tecnología biométrica es capaz de estimar un grado de similitud con el rostro de los espectadores que se sitúen frente a la obra. Mientras tanto, la pantalla muestra en tiempo real el "parecido" entre ambas personas traducido en porcentajes (Fig. 1).

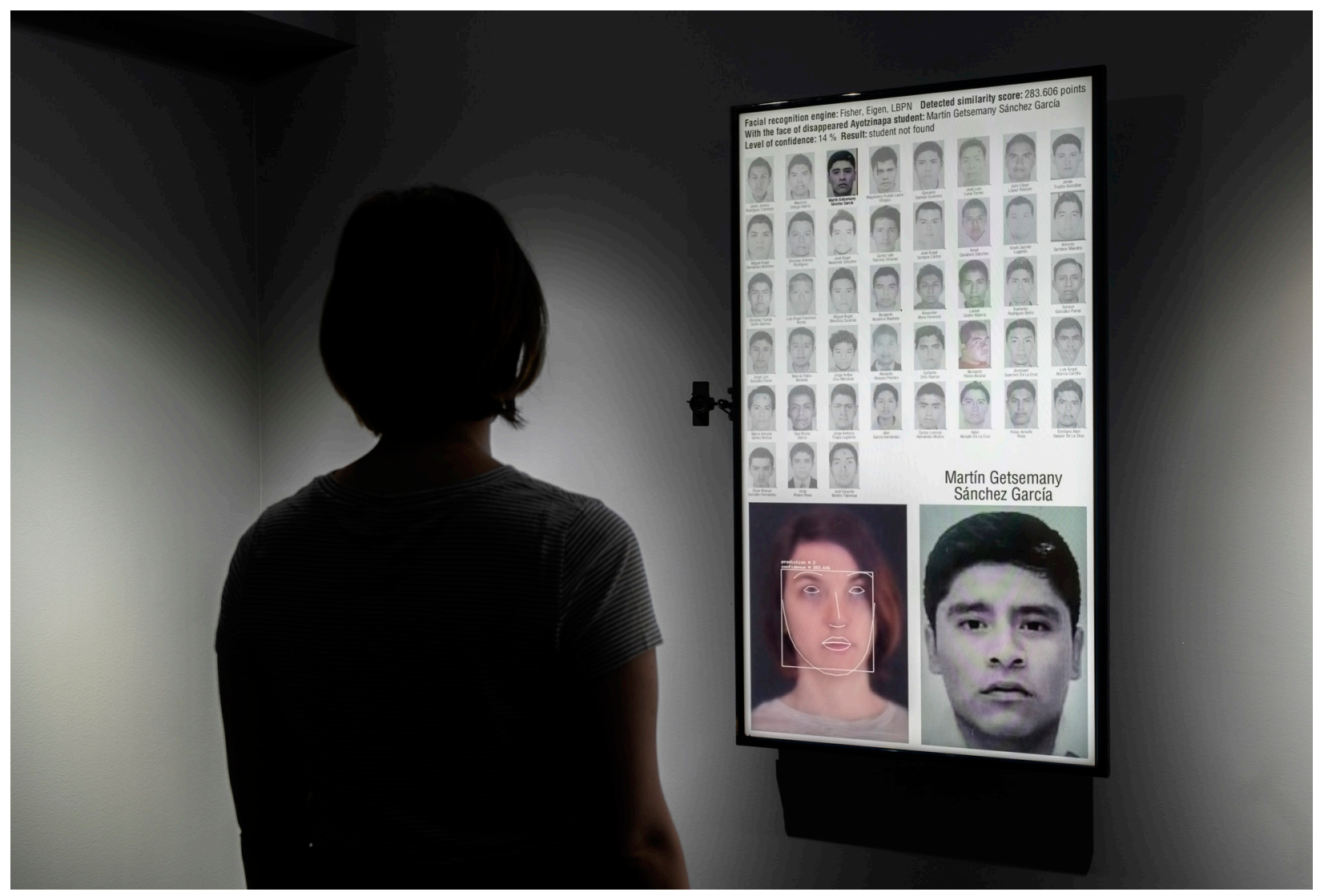

Fig. 1. Rafael Lozano-Hemmer, Nivel de confianza, 2015. Montréal (Québec, Canadá), Musée d'Art Contemporain de Montréal, 2018. Foto: Guy L’Heureux.

Para diseñar el programa, Lozano-Hemmer rastreó las fotografías de cada estudiante a través de redes sociales y de personas cercanas a los familiares. El principal objetivo de la pieza es que el público interiorice la búsqueda de los estudiantes, pero también se pretende continuar haciendo presentes a los estudiantes en los medios y en las exposiciones. De esta manera se evidencia que la búsqueda no ha de cesar mientras no sean encontrados. Para lograr estos objetivos el plan de Lozano-Hemmer fue distribuir el proyecto lo máximo posible, por lo que desarrolló un software de descarga gratuita disponible para que cualquier universidad, centro cultural, galería o museo que desee configurar la pieza y exhibirla, pueda hacerlo ${ }^{42}$ (Fig. 2). Además, el proyecto puede ser modificado para la búsqueda de otros desaparecidos, descargando el código fuente en la misma página. Esto implica una gran trasparencia y un alto nivel de accesibilidad a la pieza, flexibilidad y adaptabilidad potencial para situaciones similares.

${ }^{42}$ Para descarga de software e indicaciones, véase https://github.com/antimodular/Level-of-Confidence 


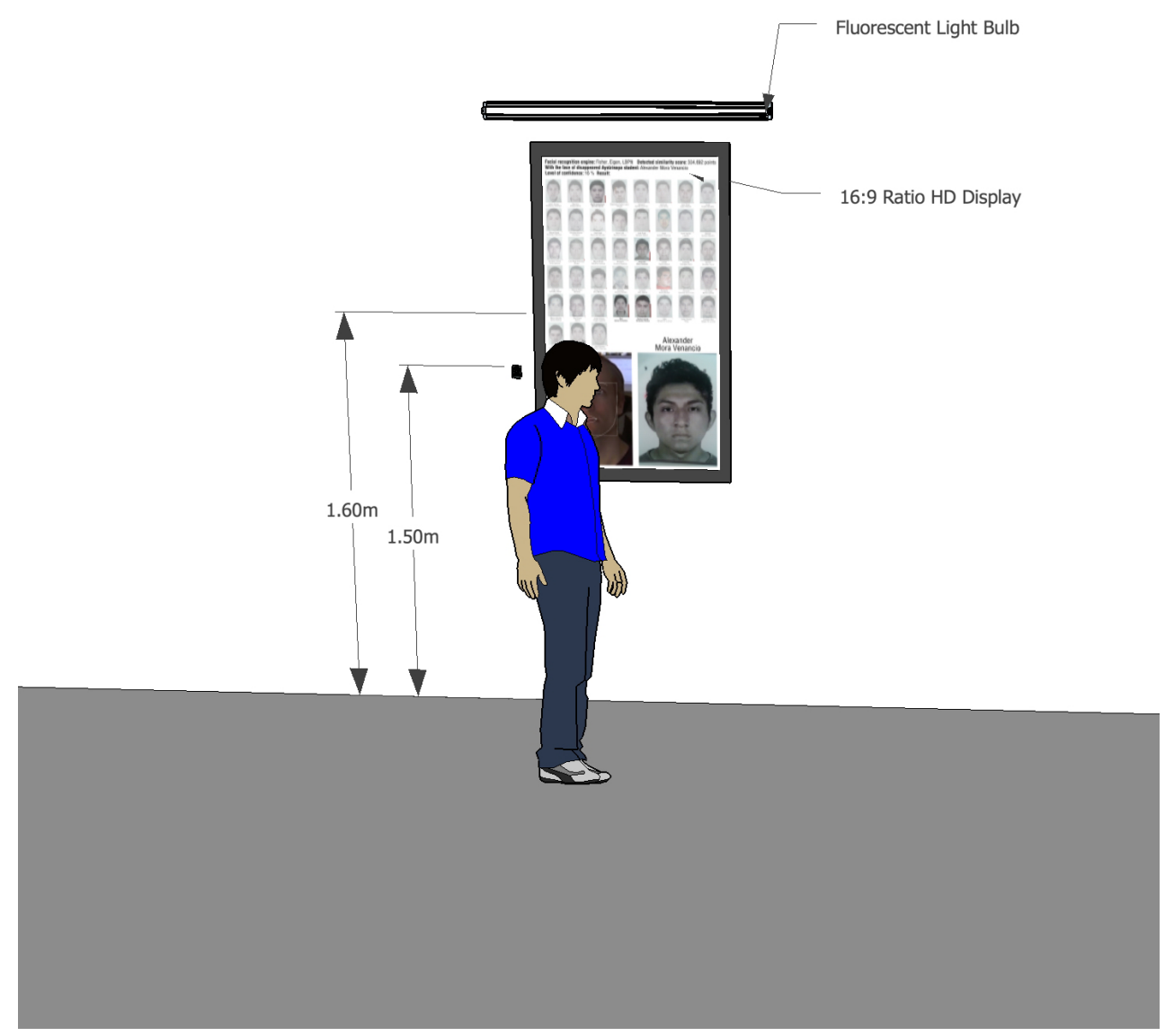

Fig. 2. Descripción museográfica de la pieza Nivel de confianza de Rafael Lozano-Hemmer (renderización en 3D).

Es evidente que la pieza no arroja un resultado positivo. Con este proyecto se persigue empatizar con la problemática del acontecimiento y de las personas afectadas por el mismo. Además, la incapacidad de la máquina para encontrarlos nos confronta con la desaparición, pues la herramienta no puede predecir ni ayudar a la localización de los estudiantes, si serán encontrados o a dilucidar en qué condiciones se encuentran. Simplemente pone al público frente a los rostros de quienes no están, de quienes no se sabe si siguen existiendo.

Vigilancias: surveillance $y$ sousveillance

Nivel de confianza propone interactuar con la obra desde la manera en que el público se sitúa frente a ella, tomando una postura corporal y política frente a la desaparición. Georges Didi-Huberman reflexiona sobre la acción de tomar posición frente a las imágenes y expone que no es un gesto sencillo, pues significa situarse dos veces, por lo menos, sobre los dos frentes que conlleva toda posición ${ }^{43}$.

${ }^{43}$ Georges Didi-Huberman, Cuando las imágenes toman posición. El ojo de la historia 1, traducción de Inés Bértolo (Madrid: A. Machado Libros, 2008), 11. 
El artista propicia este acercamiento con ayuda del sistema biométrico. Según el investigador Steve Mann, cuando un sistema de vigilancia es utilizado con el objeto de que "unos pocos, puedan observar a varios" ${ }^{4}$, puede entenderse como surveillance (del francés sur -"sobre" o "desde arriba"- y veiller -"observar"-), que se traduce como la vigilancia policial bajo la que se encuentran sospechosos, prisioneros o similar ${ }^{45}$. En este sentido la mirada y la vigilancia policial es metafóricamente vertical, una especie de panóptico que permite mirar desde arriba. Por otro lado, Mann acuñó el término sousveillance (del francés sous -“debajo"- y, nuevamente, veiller -"observar"-) que definió como una observación o grabación por parte de una entidad que no esté en posición de poder o autoridad sobre el sujeto que se vigila ${ }^{46}$, es decir, el que observa tiene un nivel de jerarquía distinta a la autoridad. Por tanto, este es un tipo de resistencia colectiva en donde los dispositivos tecnológicos documentan las atrocidades o abusos de poder cometidos por las figuras de autoridad.

Es posible relacionar la acción de sousveillance con el trabajo de Lozano-Hemmer en el sentido de que con su pieza es factible subvertir la mirada surveillante y hacer que varios, artista y espectadores, puedan observar a unos pocos: los desaparecidos ${ }^{47}$. Así, Nivel de confianza dirige la mirada a la búsqueda de los desaparecidos desde un sistema de vigilancia utilizado por la autoridad, realizando una labor que estos últimos no han sido capaces de hacer, dejándolos, así, en evidencia.

Para Mann, la acción sousveillante requiere de un tipo de vigilancia más participativa. Por ejemplo, si una conversación telefónica es grabada por uno de los involucrados, es sousveillance, pero si la conversación es grabada por alguien que no participa dentro de ella, es una vigilancia desde arriba, surveillance $e^{48}$.

Es en este sentido, la obra de Lozano-Hemmer posiciona a la persona frente a la tecnología de vigilancia y la anima a tomar posición frente a la imagen de los desaparecidos. Los implica en la búsqueda de los desaparecidos y testimonia, con las fotografías de los estudiantes como evidencia de su ausencia, la tecnología represiva de la desaparición. Finalmente, la pieza no es posible sin la observación-participación de quien observa: los espectadores deben de estar dispuestos a que su rostro sea leído e identificado desde la tecnología biométrica.

\section{Biometría y resistencia}

Las tecnologías de identificación como la biometría requieren técnicas de normalización creadas previamente que luego operan como plantillas comunes para la regulación, la gestión y la gobernanza. Estas tecnologías están calibradas desde "patrones preexistentes" con preconceptos culturales que construyen biométricamente la facilidad teniendo como referente el de un "cuerpo promedio": hombre blanco, joven y sano. Dichos datos son "notoriamente sospechosos, incompletos, fáciles de manipular y plagados de prejuicios raciales"49.

Estas tecnologías poseen un alto índice de error pues no son capaces de registrar ciertas diferencias que tienen importantes connotaciones raciales y de clase. La industria biométrica es incapaz de registrar la singularidad y la diversidad, como huellas dactilares desgastadas por algún trabajo manual, cicatriz o arrugas, o por problemas vinculados a la piel como la dermatitis. En cuanto a la lectura facial, en ocasiones no es

${ }^{44}$ Steve Mann, "Veilance and reciprocal transparency: Surveillance versus sousveillance, AR glass, lifeglogging, and wearable computing", en 2013 IEEE International Symposium on Technology and Society (ISTAS): Social Implications of Wearable Computing and Augmediated Reality in Everyday Life (Toronto: IEEE, 2013), 1-12, https://doi.org/10.1109/ISTAS.2013.6613094.

45 Mann, "Veilance", 3.

46 Mann, "Veilance", 3.

47 Mann, "Veilance", 1.

48 Mann, "Veilance", 4, 7.

49 Wendy Hui Kyong Chun, “Queerying Homophily”, en Clemens Apprich, Wendy Hui Kyong Chun, Florian Cramer, e Hito Steyerl, Pattern Discrimination (Minneapolis: University of Minnesota Press, Meson Press, 2018), 63. 
posible leer pieles más delgadas o pieles oscuras y la lectura del iris presenta dificultades si la persona tiene alguna discapacidad visual ${ }^{50}$.

La facialidad es entendida por Gilles Deleuze y Félix Guattari como una máquina de dominación racial y colonial. Esta crea categorías de identidad binarias de "sí o no" (si un cuerpo pasa, o no) en las que el sujeto se ubica de acuerdo con el Estado. De modo que las elecciones de "sí-no" deciden qué rostros se ajusta a la imagen del Estado y qué rostro representa una amenaza. Lo que produce un reforzamiento de prácticas policiales desproporcionadas y discriminatorias ${ }^{51}$.

Por tanto, el racismo europeo, como el reclamo del Hombre Blanco, nunca ha operado por exclusión. El racismo opera con la vinculación de las personas con sus iguales. A esto, la investigadora de nuevos medios Wendy Hui Kyong se refiere como homofilia (homophily): "love as love of the same, closes the world it pretends to open" 52 . Desde este punto de vista, en el racismo no hay afuera, solo hay personas que deberían ser como "nosotros" cuyo crimen es no serlo. El racismo nunca detecta las partículas del otro, sino que, como señalan Deleuze y Guattari, solo propaga olas de igualdad ${ }^{53}$. Por tanto, si desde los estándares del Estado no se reconoce una cara y se selecciona el "no", se niegan los derechos del sujeto ${ }^{54}$. El artista Zach Blas expone que la vigilancia puede aumentar rápidamente a escala mundial, pero que con tales estándares de identificación se trabaja eliminando la diversidad, la alteridad queda fuera de la programación, resultándole opaca. Tal y como Blas concluye, quienes son computacionalmente ilegibles son excesivamente vulnerables a la violencia, la discriminación y la criminalización ${ }^{55}$.

Así, los cuerpos no entran y no caben dentro de las normativas raciales de identificación, son cuerpos de las periferias, como los de los estudiantes de Ayotzinapa. Esta opacidad también se ha utilizado a favor de ciertas acciones de resistencia contra el Estado y sus políticas de identidad e identificación, rechazando la captura y el reconocimiento facial desde protestas enmascaradas como las de Anonymous, Pussy Riot o los Zapatistas. El mismo Blas utiliza el término de opacidad para hacer referencia a una técnica de transformación estética que se esfuerza por subvertir la normalización de la identificación a través de la creación de máscaras ininteligibles para los mecanismos biométricos ${ }^{56}$.

Se podría considerar que Lozano-Hemmer traslada la noción de opacidad a otro campo de lectura distinto al de Blas pues los rostros de los desaparecidos ya son opacos. En la fotografía comparten una estética opaca, rostros grises, unificados, retratados en fotografías desgastadas, que hablan de una condición distinta, la del desaparecido. En este caso la resistencia requiere una visibilidad de lo opaco que incomoda a aquellos que preferirían que el caso quedara cerrado, invisibilizado. Precisamente, Lozano-Hemmer concibe la tecnología desde nuestro agenciamiento con ella: no deja pie a la neutralidad y comprende los preconceptos desde los cuales es utilizada y construida.

\section{Vulnerabilidad}

La desidentificación, esa opacidad que viven las minorías como respuesta a su situación precaria debido a las restricciones y estigmas ideológicos, es lo que Judith Butler denomina sujetos inviables sin existencia

\footnotetext{
${ }^{50}$ Alejandra Labastida, "Tercero incluido o la máquina y su doble", en Rafael Lozano-Hemmer: Pseudomatismos (México: MUAC, UNAM, 2015), 16.

${ }^{51}$ Andie Shabbar, "A Queer Politics of Imperceptibility: A Philosophy of Resistance to Contemporary Sexual Surveillance" (Tesis doctoral, University of Western Ontario, 2018), 201, https://ir.lib.uwo.ca/etd/5973; Kyong Chun, “Queerying”, 63.

52 Kyong Chun, "Queerying”, 60.

53 Gilles Deleuze y Félix Guattari, Mil mesetas. Capitalismo y esquizofrenia (Valencia: Pre-Textos, 2004$), 384$.

${ }^{54}$ Shabbar, "A Queer", 201.

55 Zach Blas, "Informatic Opacity”, The Journal of Aesthetics and Protest 9 (2014), http://joaap.org/issue9/zachblas.htm

56 Zach Blas, "Informatic Opacity".
} 
social ${ }^{57}$. Consideramos que la pieza de Lozano-Hemmer subvierte la "inexistencia" de esos sujetos por medio de las tecnologías de vigilancia, que devienen engranajes de resonancia y de vinculación.

De esta manera, Lozano-Hemmer visibiliza a aquellos que no entran en esas olas de igualdad, ni gozan de los mismos derechos. En Nivel de confianza "los desaparecidos", "los 43", conservan su rostro, su nombre, dejan de ser un número y se visibilizan su individualidad, sus diferencias y también sus coincidencias, además de las relaciones con quien los observa (Fig. 3).

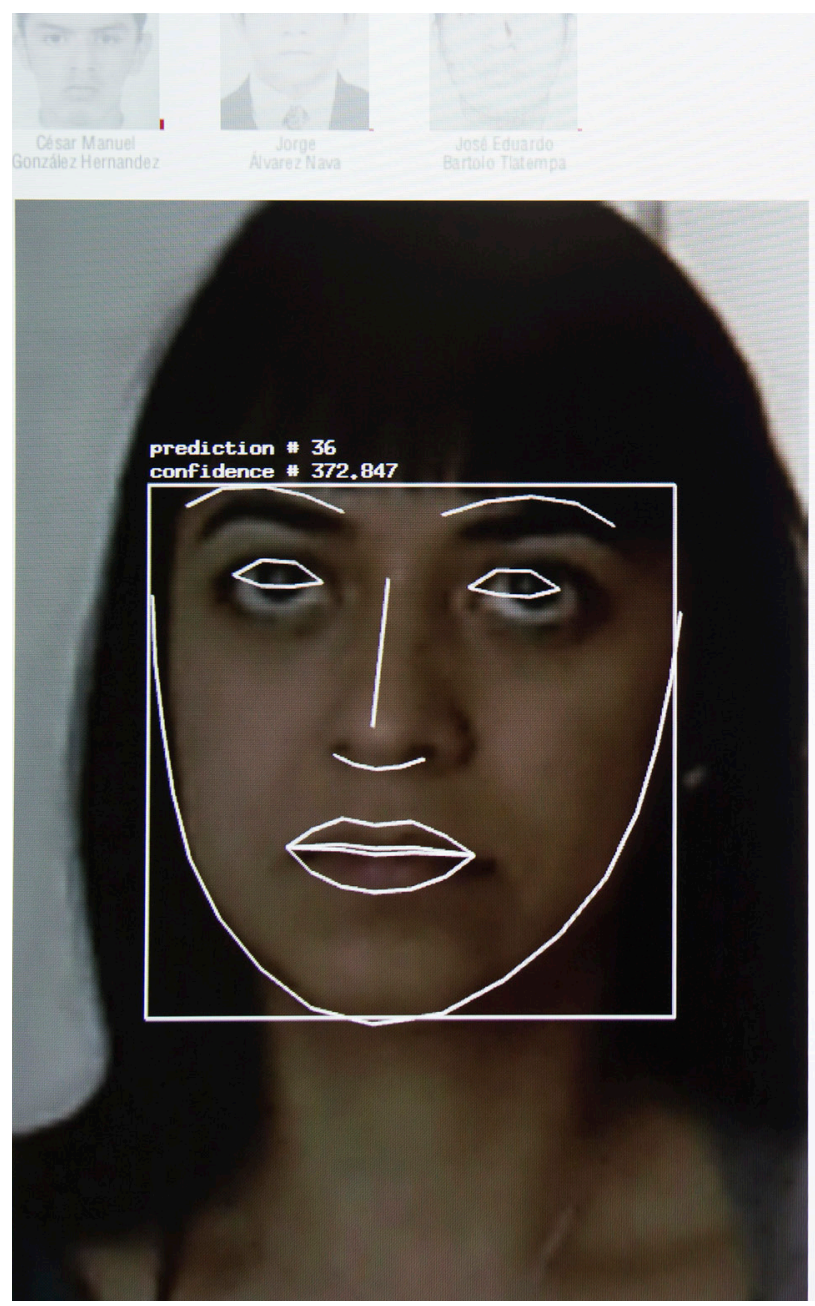

\section{Carlos Lorenzo Hernández Muñoz}

Fig. 3. Rafael Lozano-Hemmer, Nivel de confianza, 2015. Montréal. Foto: Antimodular Research.

Cuando guardamos luto por unas vidas y reaccionamos con frialdad ante la pérdida de otras, estamos reaccionando de acuerdo a lo que Judith Butler nombra como los campos de "reconocibilidad". La manera de ser considerada una persona en el mundo depende de las redes de sociabilidad y políticas en las que vive el cuerpo, por lo que ciertos tipos de cuerpos parecerán más precarios que otros según cómo estén circunscritos en la vida humana; si son merecedores de cobijo, de protección y de vivir,

57 Judith Butler, citada por Sebastian Althoff, "Inhabiting the Profile: Zach Blas' Facial Weaponization Suite", Intermediality. History and Theory of the Arts, Literature and Technologies, 32 (2018): 1-20, https://doi.org/10.7202/1058472ar. 
son merecedoras de duelo ${ }^{58}$. Es decir, nuestra capacidad de responder con indignación depende de un reconocimiento de que existe una vida meritoria que se ha dañado. Pero justo ahí se encuentra nuestra responsabilidad hacia quienes no conocemos, hacia el otro, hacia quienes parecen poner a prueba nuestro sentido de pertenecer ${ }^{59}$.

En el caso de los estudiantes de Ayotzinapa, el contexto del que provienen no es reconocido. Sin embargo, su estatuto como estudiantes hizo visible la precarización de su vida. Las investigaciones sobre el caso llevaron a encontrar fosas clandestinas llenas de cuerpos por los que no se guardó luto, que no eran estudiantes, que ni la sociedad mexicana ni el Estado, lamentablemente, consideraron que eran meritorios de ser llorados. Lo que sacó a la luz el caso también fue esa autorreferencialidad del cuerpo que está intrínsicamente ligada al contexto vivido. Sacó a la luz el contexto gore en el que está sumido el país.

Para Butler, el cuerpo como fenómeno social está expuesto a los demás y es vulnerable por definición. Por tanto, es la "vulnerabilidad" lo que nos une, pues todos hemos experimentado haber perdido a alguien. Somos seres en falta, seres de duelo. Reconocer esa "vulnerabilidad" y dependencia con los otros cuerpos no es sinónimo de pasividad, enajenación o victimización; al contrario, Butler incita a liberarnos de esa posición binaria entre vulnerabilidad y agencia-acción-resistencia para reconocer su poder de movilización ${ }^{60}$.

En este proceso de vincularme al sentir del otro como parte de mí, reconozco la "vulnerabilidad", que da paso a poderla reconstruir. Reconocer (del prefijo "re", de repetición, movimiento hacia atrás y del latín cognoscere, conocerse) implica un volver a conocer-nos. Pero también implica una pérdida del desconocimiento del yo para poder aproximarme al otro.

Desde esta posición, la pieza de Lozano-Hemmer realiza un acto de reconocimiento en el que incorpora al otro a mi propio rostro. En este sentido, el nosotros queda atravesado por una "relación nosótrica" ${ }^{\prime}$. Esto no significa que seamos lo mismo, más bien estamos unidos por lo que nos diferencia, por nuestra singularidad y esa singularidad tiene, al mismo tiempo, propiedades en común con el otro. Como bien dice Lozano-Hemmer, esa relación de parentesco es invocada como condición de posibilidad para asumir una responsabilidad colectiva por las vidas físicas de los otros ${ }^{62}$.

En Nivel de confianza esto se traduce de pasar a "ese podría ser yo, podría ser mi hermano" a asumir "soy yo y es mi hermano" 63 . Nos sumerge en la búsqueda de la desaparición y nos enfrenta a ella desde nuestra corporalidad, recordándonos nuestra condición vulnerable. Es una poética de la desaparición, de un posible duelo, que nos muestra que estamos expuestos a los demás. Esto implica, primero, volver a conocer-nos, re-conocer-nos, frente a frente, rostro con rostro, es ahí donde, como señala Butler, surge lo humano ${ }^{64}$. Nivel de confianza nos coloca frente a nuestros preconceptos culturales, raciales e identitarios para recordarnos nuestra esencia humana, que no es posible nuestra existencia sin el otro. Hace posible que el dolor del otro sea un estremecimiento en todos los cuerpos. En este sentido, la obra de LozanoHemmer exige tomar una ubicación y postura ante la pieza que, sea cual sea, será política, pues toda posición lo es.

58 Althoff, "Inhabiting the Profile".

59 Judith Butler, Marcos de guerra. Las vidas lloradas (México: Editorial Paidós Mexicana, 2010), 61.

${ }^{60}$ Labastida, "Tercero incluido", 18.

${ }_{61}$ Término acuñado por el investigador Carlos Lenkersdorf, retomado de las comunidades mayas tojolabal y tzeltal que refiere a un principio organizativo a nivel socio-político desde donde se construye el sentido de comunidad. Cfr. Carlos Lenkersdorf, "Nosotros, otra realidad", Comunicacão \& política 7, n. ${ }^{\circ} 2$ (2000): 161-79.

${ }^{62}$ Judith Butler, Dar cuenta de sí mismo. Violencia, ética y responsabilidad (Buenos Aires: Amorrortu, 2009), 52-53; Rafael Lozano-Hemmer, "Nivel de confianza".

${ }^{63}$ Mónica Nepote, "Nivel de confianza: una pieza de Rafael Lozano Hemmer", Revista 404, 13 de junio de 2015, https:// editorial.centroculturadigital.mx/articulo/nivel-de-confianza-una-pieza-de-rafael-lozano-hemmer.

${ }^{64}$ Judith Butler, Vida precaria: el poder del duelo y la violencia (Buenos Aires: Paidós, 2006), 71-72, 78. 


\section{Huella, borradura y desaparición: mal de archivo y posverdad}

El archivo puede romper las imágenes preestablecidas, lo que posibilita una pluralidad de lecturas que dan cabida a nuevos territorios de pensamiento y saber.

Arlette Farge ${ }^{65}$

La desaparición implica la acción de "quitar de la vista". Una persona desaparecida no desaparece por error, sino gracias a una tecnología represiva específica por un conjunto de acciones, omisiones, confusiones, en las que participan muchos agentes cuya misión es hacer desaparecer ${ }^{66}$. La desaparición, según Hito Steyerl, es un lugar de "indeterminación". Si un objeto desaparece no es posible conocer más sus condiciones materiales: si ha sido destruido o sigue intacto. En el caso del desaparecido es no saber si está vivo o muerto. La posibilidad de saber nuevamente sobre el objeto es volverlo a observar, sentir su materialidad y las condiciones de su existencia. Esta "indeterminación" se relaciona de cierto modo con la de la "Ley General en Materia de Desaparición Forzada en México" que aboga por la presunción de vida; esto significa que, para llevar a cabo el proceso y mecanismos de búsqueda, las autoridades deben presumir que la persona desaparecida está con vida ${ }^{67}$.

Este estado de "indeterminación" supone a la persona desaparecida como probablemente-muerta-perolegalmente-viva. Esto, por un lado, permite que los procesos legales continúen abiertos y, por el otro, dota a la persona desaparecida de cierta agencia espectral, una inmaterialidad del no estar, pero que demanda respuestas con su sola ausencia. Es el espectro de Jacques Derrida, ese otro que aparece como reaparición de lo desaparecido ${ }^{68}$. De ahí que una de las consignas más representativas de las protestas de Ayotzinapa fuera “ $i V i v o s$ se los llevaron, vivos los queremos!". En un principio fue un mensaje contundente para encontrar a los estudiantes vivos, pero se convirtió en un mensaje que alude al estado de "indeterminación" y posibilita que el caso siga abierto a modo de recordatorio: "siguen vivos porque el crimen sigue vigente". Por tanto, la figura del desaparecido emerge en su forma política, jurídica, simbólica y espectral, y con ella la demanda política y afectiva que encarna.

De esta forma, el desaparecido cumple con dos condiciones: no debe ser hallado como mandato del poder, pero a la vez debe ser buscado ineludiblemente por la sociedad. Es quien reposa en lo secreto, en lo perdido y que el poder soberano busca que continúe en ese sitio. Sus familiares son quienes buscan y cavan la condición de posibilidad para dar fin a la "indeterminación". La desaparición implica la ausencia de vínculos afectivos entre vivos y muertos. No hay trabajo de duelo, no hay Día de Muertos, solo confusión y duda.

Esto se relaciona con lo que Jean-Louis Déotte denominó como "aparato estético", el cual hace posible la aparición de la sensibilidad de una comunidad y una época, como son la perspectiva, la cámara oscura, el museo, la fotografía, el cine o el video. El "aparato", además, produce sus medios de visibilidad para la existencia de un común. Entendida la visibilidad en relación con aquellas cosas y personas visibles y los invisibles, desde Jacques Rànciere, estos últimos serían los sin-parte. Podría agregarse: los sin-nombre, los no-vistos ${ }^{69}$.

\footnotetext{
65 Arlette Farge, La atracción del archivo (Valencia: Edicions Alfons el Magnànim, 1991), 36.

66 "Disappearance / Search", Ecologies of Migrant Care, consultado el 30 de mayo de 2020, https://migration.hemi.press/ disappearance-search/; Carlos Fazio, “Ayotzinapa, terror clasista”, La Jornada, 13 de octubre de 2014, https://www.jornada.com. $\mathrm{mx} / 2014 / 10 / 13 /$ opinion/020a1pol

${ }^{67}$ Hito Steyerl, Los condenados de la pantalla, traducción de Marcelo Expósito (Buenos Aires: Caja Negra Editora, 2014), 144, 147. Ley General en Materia de Desaparición Forzada de Personas, Desaparición Cometida por Particulares y del Sistema Nacional de Búsqueda de Personas, y se reforman y derogan diversas disposiciones del Código Penal Federal y de la Ley General de Salud (Diario Oficial de la Federación, 17 de noviembre de 2017), 5.

68 Derrida, Espectros, 20.

69 Jean-Louis Déotte, "México: el desafío estético de la desaparición forzada", Revista CUHSO. Cultura-Hombre-Sociedad 25, n. ${ }^{\circ} 1$ (julio 2015): 43, https://doi.org/10.7770/cuhso-V25N1-art900; Jean-Louis Déotte, "El aparato estético. Un diálogo en torno del aparecer técnico de las artes", entrevistado por Laura González-Flores en Historia del arte y estética, nudos y tramas. XXIX Coloquio Internacional de Historia del Arte (Instituto de Investigaciones Estéticas, UNAM, 2019), 177, 181; Jacques Rancière, El reparto de lo sensible. Estética y política (Santiago de Chile: LOM Ediciones, 2009), 9-10.
} 
Para el caso que nos ocupa, los invisibles, los no reconocidos, los desaparecidos, pueden compartir de otro modo lo sensible para volverse visibles. De este modo se necesita aparecer, sometiéndose al "aparato estético" dominante. Esto puede transformar al invisible en "digno" de aparecer. Según Déotte, solo si seguimos esa aproximación se podrá descubrir un hacer-mundo y un hacer-época ${ }^{70}$. Lozano-Hemmer no solo se "sometió" al "aparato estético" dominante del museo, también empleó el de la fotografía y el de la tecnología biométrica para mostrar a los desaparecidos como "dignos" de aparecer. Además, la desaparición conlleva un problema de representación, pues no es posible representar lo que ha desaparecido, no es posible divisar ni un lugar ni un tiempo concreto.

Lo narrado o expresado es un acto de representación, esto es, un acto social de negociación. Esa negociación, a su vez, es una representación. Para que la política ocurra se necesita negociar el suceso. En el caso de Nivel de confianza la representación-negociación se realiza a través de las imágenes tipo credencial de los estudiantes. Se trata de rostros en blanco y negro, nebulosos, rostros desaparecidos utilizados generalmente en las manifestaciones. Estas imágenes fotográficas comparten ese registro de dicha agencia espectral de la ausencia del desparecido. La acción de poner los espectadores ante estas fotografías lleva a pensar, sentir, observar, incluso a buscar a su referente frente a nuestros ojos.

La desaparición requiere volver a la certeza de que las personas existieron realmente. De ahí el uso del retrato fotográfico en las protestas, pues la fotografía actúa como ese "archivo" de la existencia contra la incertidumbre, como menciona Nelly Richard: "tanto la huella fotográfica como la desaparición conjugan el ya no y el todavía" ". Es ese rastro el que confirma, en la "indeterminación", un halo de la existencia.

\section{Archivo, mal de archivo y posverdad}

Ese rastro lo podemos encontrar también en la noción de "archivo". Para Jacques Derrida el "archivo" contiene algunas de sus características en su propia etimología. La palabra "archivo" proveniente de la raíz griega arkhé, que contiene dos significados: comienzo y mandato: es allí donde las cosas comienzan. Al mismo tiempo, también está regido por el principio de la ley, del nómos, es allí donde se ejerce la autoridad. El pensar el allí significa también ocupar sitio en el arkhé, es decir, una casa, un arkheîon, que era la residencia del "archivo" y los arcontes, los que mandaban y se les reconocía el derecho de representar la ley. Ellos no solo se encargan de la seguridad física del depósito y del soporte, sino que también tienen el poder y el privilegio de interpretar los archivos. Ese allí puede inscribirse en instituciones con una inclinación importante hacia el registro, la conservación y el resguardo, un museo, una biblioteca o un "archivo" general"

La paradoja del "archivo" se encuentra en el deseo de conservarlo todo, en el conjunto de operaciones de custodia, conservación e interpretación y cómo esto establece una relación específica con el tiempo, la memoria y el olvido. El "archivo" no puede existir sin la posibilidad de olvido, sin la amenaza de destrucción del mismo. Así, el rastro, la huella y la ceniza forman parte del cuerpo del "archivo". A esto Derrida lo llamó "mal de archivo". Este mal es la "pulsión de muerte" que retoma Derrida de Sigmund Freud. El mal que envuelve al "archivo" se muestra como una espectrografía latente, es ese borrarse. En esta relación, la estructura del "archivo" es espectral, una "huella que remite siempre a otro con cuya mirada no podríamos cruzar la nuestra"73. Entonces, el "archivo" no solo puede entenderse como un conjunto de documentos

${ }^{70}$ Jean-Louis Déotte, ¿Qué es un aparato estético? Benjamin, Lyotard, Rancière (Santiago de Chile: Ediciones metales pesados, 2012), 39.

${ }^{71}$ Nelly Richard, "Imagen-recuerdo y borraduras", en Politicas y estéticas de la memoria (Santiago de Chile: Editorial cuarto propio, 2000), 172.

72 Jacques Derrida, Mal de archivo (Valladolid: Trotta, 1997), 9-11.

73 Derrida, Mal de archivo, 92; Ricardo Nava Murcia, Deconstruir el archivo: La historia, la huella, la ceniza (México: Universidad Iberoamericana, 2015), 159. 
reunidos y custodiados en un lugar, sino como un sistema articulado de signos, nunca completos, sin ser un corpus absoluto, pero con tendencia a serlo y con una lejanía hermenéutica trastocada por el tiempo.

En este sentido, el trabajo arcóntico de Lozano-Hemmer, está en un contacto continuo con el "archivo" fotográfico de los estudiantes, con esa ceniza y esa falta. Su obra no se completa, pues el "archivo" no logra encontrar a su idéntico. Ahí queda claro que ese corpus que trata de ser "absoluto" nunca está completo.

La pieza de Lozano-Hemmer marca con una línea roja vertical el grado de similitud que el rostro de la persona tiene con el de los estudiantes (Fig. 4). Los rasgos de los espectadores también se convierten en datos que evidencian la falta. El algoritmo otorga un puntaje en función del parecido con cada fotografía y selecciona aquella para la cual este es mayor. Esto se traslada luego a un porcentaje denominado "nivel de confianza". Estos datos se muestran en la pantalla junto con la fotografía y el nombre del estudiante con quien la similitud es mayor. Y luego da el resultado final: "estudiante no encontrado". En Nivel de confianza está presente el acto de registro y de reunión.

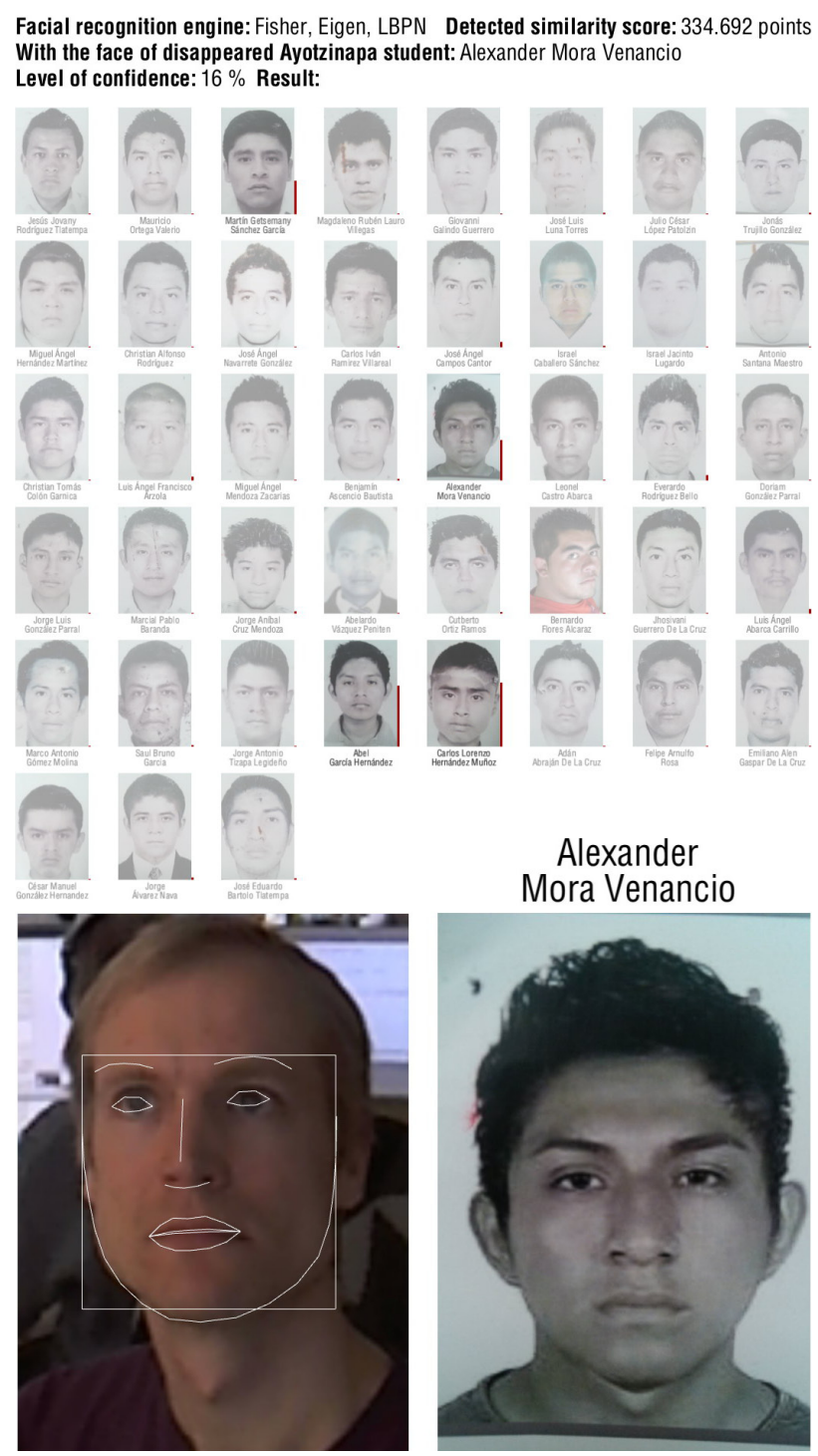

Fig. 4. Rafael Lozano-Hemmer, Nivel de confianza, 2015. Montréal. Foto: Antimodular Research. 
Este acto de reunión es el poder de consignación de Derrida, entendido no solo como el hecho de poner en reserva, en un lugar o sobre un soporte, sino como el acto de consignar reuniendo los signos. De ahí que la importancia del "archivo" también radique en cómo mirarlo: los "archivos", más allá de ser depósitos de material antiguo, son lugares activos donde se negocia e impugna, pues se encuentran en un rehacer continuo $^{74}$. Lozano-Hemmer encara el problema de cómo mirar el "archivo". Más allá de una cuestión del pasado, comprende que el "archivo" contiene esa responsabilidad de cómo podrá ser leído en el "por-venir", entendido desde Derrida como ese abrirse a lo imprevisible. Es una renuncia al saber que termina sabiendo lo ya sabido. Solo así es posible dar pie a la aparición de lo sorpresivo, lo otro, aquello que cuestiona y pregunta los supuestos saberes, certezas y legalidades dados y abre la posibilidad de pensar históricamente lo que aún está por-venir ${ }^{75}$.

Por su parte, Arjun Appadurai menciona que las predeterminaciones y agencia del "archivo" provienen de los usos que hacemos de él, no del "archivo" en sí mismo. Así, este se construye por accidentes que producen rastros, con intencionalidades, e incluso, desapariciones ${ }^{76}$. Con esto, no solo se enfrenta al "mal de archivo", también al campo de visión que se tiene sobre él, es decir, su arco de preguntas y formas de escritura de una historia. En este sentido la "verdad histórica" del caso Ayotzinapa se dio como mandato de la versión oficial y del ocultamiento de otra parte de la narrativa ${ }^{77}$.

En este punto las imágenes comienzan a verse envueltas en conflictos sobre la autenticidad, veracidad e interpretación. Veracidad entendida como un acuerdo de confianza que se ajusta a la "verdad" y está íntimamente ligada con el "archivo" y el registro, pues si está registrado o documentado, parece ser que existe ${ }^{78}$. De esta manera, "verdad" y "archivo" encuentran su vínculo.

Dentro del proceso de investigación de Ayotzinapa hubo muchas mentiras, fue un simulacro que trabajó desde una lógica muy bien reconocida dentro del sistema judicial mexicano y que consiste en ocultar, borrar, ignorar. No es una lógica intelectualmente procesada con mecanismos complejos, es una lógica aprendida: se destruyeron las pruebas como un procedimiento rutinario, de burocracia extrajudicial, no se pensó que esto pudiera tener las repercusiones que tuvo. De esta manera se construyó una "verdad histórica", una conclusión basada en mentiras sin asidero, construida con piezas que nunca encajaron. Aunque en el proceso hubo muchas mentiras, la "verdad histórica" no fue propiamente una mentira, pues la mentira requiere de un ocultamiento de la verdad. La "verdad histórica" se convirtió en la forma por la cual borrar las posibles verdades. Pero ¿cómo es posible hacer frente a este juego entre ficción, "posverdad” y mentira?

Steyerl se preguntó: “¿Y si la verdad no se encuentra ni en lo representado ni en la representación? ¿Y si la verdad se encuentra en la configuración material de la imagen?"79. Estas preguntas me permitieron centrar el problema de la "verdad" del caso de estudio a partir de la configuración material de la imagen. Para ello se requiere estudiar las imágenes como cosas, como parte del mundo material. En este sentido, la materialidad también aporta un cierto modo de lectura de los registros. De esta manera se direcciona la manera de hacer hablar a los archivos, incluso a las imágenes.

Se puede hacer hablar a las imágenes mediante procesos de materialización. De esta manera, es posible

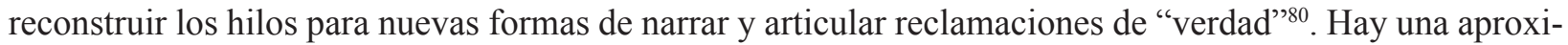

${ }^{74}$ Ernst van Alphen, Escenificar el archivo. Arte y fotografía en la era de los nuevos medios (Salamanca: Ediciones Universidad de Salamanca, 2014), 18; Derrida, Mal de archivo, 34.

75 Nava Murcia, Deconstruir el archivo, 88- 90.

76 Arjun Appadurai, "Archive and Aspiration", en Art and Theory on Archiving and Retrieving Data, eds. Joke Brouwer y Arjen Mulder (Rotterdam: V2 /NAi Publishers, 2003), 15-16.

77 Bárbara Barahona Garrido y Hellmuth Herlitz Cifuentes, "Archivos de la represión en Chile: entre el acceso y la desclasificación”, Serie Bibliotecología y Gestión de Información 99 (2017), http://eprints.rclis.org/31495/1/Serie\%20N\%C2\%B099\%203.ed..pdf.

78 Jorge Luis Marzo, "Exhumar la verdad y dejar que huela", en FAKE, no es verdad, no es mentira, coords. Jorge Luis Marzo y Marta Arroyo Planelles (Valencia: IVAM, 2016), 13.

79 Steyerl, Los condenados, 54.

${ }^{80}$ Marzo, "Exhumar la verdad", 13. 
mación del objeto por su valor documental, de alguna manera archivístico, con un formato de veracidad y con todas las posibilidades hermenéuticas que presenta. La carga afectiva por el objeto no se centra en la política de la memoria y el duelo propiamente, se plantea como evidencia del crimen, que demanda identificación y una historia. El planteamiento político de la reconstrucción de la "verdad" se encuentra, así, en comenzar con las cuestiones materiales ${ }^{81}$.

En la pieza que nos ocupa, la materialidad se encuentra en las tecnologías de vigilancia. Y el juego con la "verdad" se encuentra en la forma de interpretación de los datos y en la memoria. Sin embargo, Steyerl plantea que se necesitan ciertos filtros interpretativos para leer los datos, pues está en juego la cuestión de cómo y en qué medida ciertos patrones de lectura se basan en creencias racistas, sexistas y clasistas. A estos filtros ella los llama patrón de discriminación (pattern of dicrimination). Al aplicar estos filtros se permite la re-creación de los datos y, por tanto, la forma en que re-creamos la realidad ${ }^{82}$.

En consecuencia, Lozano-Hemmer plantea la posibilidad de leer la realidad desde la tecnología biométrica aplicando ciertos filtros interpretativos que permitan otro acercamiento a la construcción de realidad sobre el caso de Ayotzinapa. Por ejemplo, la lectura biométrica desde la horizontalidad y sousveillance. En este sentido, Lozano-Hemmer sumerge a los espectadores en la relación de vínculos afectivos, entendiendo afecto desde Suelly Rolnik "no en el sentido de cariño, sino en el sentido de ser afectado, perturbado, tocado" ${ }^{83}$. Esto es diferente de la emocionalidad que puede generar una cierta impulsividad basada en ideas poco objetivas, incluso veraces que, en ocasiones, alejan a las personas de la realidad como sucede desde la "posverdad".

Aunado a ello, el uso de la fotografía alude al ejercicio de la memoria, no solo como una evidencia fáctica de lo que sucedió. También, en términos de evocación, de hacer pasado, subrayando también sus cualidades intrínsecas y afectivas ${ }^{84}$. Por ello la fotografía juega un papel importante para comunicar lo sucedido en Ayotzinapa y una identidad construida a partir de la memoria. En consecuencia, la forma de presentar las fotografías de los estudiantes exige una reciprocidad para consolidar la memoria de las imágenes que se desea conservar socialmente ${ }^{85}$.

De esta manera, la materialidad y la forma física establecen cierto tono afectivo de las imágenes, es decir, la relación emocional a través de las asociaciones de la memoria personal y colectiva. La pieza como un álbum-fotográfico-objeto se compromete con el cuerpo, lo retemporiza trasladándolo al ahora y reespacializa las fotografías en el lugar de visión del público. La pieza de Lozano-Hemmer se convierte en un artefacto, un arte-hecho-acontecimiento y así, plantea una aproximación a la imagen por su valor documental. Se convierte en una declaración pública de evocación a la desaparición y a la exigencia de un "por-venir" en donde el acto de aparición sea posible ${ }^{86}$.

\section{Conclusiones}

Los objetos y las huellas no solo expresan de forma gráfica las lecturas biométricas. También actúan sobre las personas, transforman las autorrepresentaciones, transmutan las relaciones con el espacio y la

${ }^{81}$ Eyal Weizman, Anselm Franke y Forensic Architecture, eds., Forensis. The Architecture of Public Truth (Berlín: Sternberg Press, 2014), 67; Pablo Domínguez Galbraith, "Estéticas forenses en México: la arquitectura de lo sensible en el caso Ayotzinapa", Revista Académica Estesis 6, n. ${ }^{\circ} 6$ (2019): 93-95, https://doi.org/10.37127/25393995.41.

${ }^{82}$ Hito Steyerl "Data Paranoia How to Make Sense of Pattern Discrimination", citada por Clemens Apprich et al., Pattern Discrimination, 109, 117-118.

${ }_{83}$ Marie Bardet, “¿Cómo hacernos un cuerpo? Entrevista con Suely Rolnik”, Lobo Suelto! Anarquía Coronada, 8 de mayo de 2018, http://lobosuelto.com/como-hacernos-un-cuerpo-entrevista-con-suely-rolnik-marie-bardet/

${ }^{84}$ Elizabeth Edwards, "Photographs as objects of memory", en The Object Reader, eds. Fiona Candlin y Raiford Guins (Cambridge: Routledge, 2009), 333.

${ }^{85}$ Edwards, "Photographs as objects", 335, 339.

${ }^{86}$ Edwards, "Photographs as objects", 339. 
temporalidad, ponen en crisis la base epistémica sobre la cual podemos diferenciar lo virtual de lo real ${ }^{87}$. En este sentido, Nivel de confianza cuestiona las formas desde las cuales comprendemos el mundo y lo interpretamos.

Por otro lado, Lozano-Hemmer invita a recorrer vínculos afectivos que trastocan las relaciones humanas y las sensibilidades, al grado de girar la conversación no hacia lo que sucedió, sino hacia lo que permite sentir el caso y posibilita dejarse afectar. También viabiliza una nueva forma de re-construir la "verdad", una "verdad" a partir de la "vulnerabilidad". Verdades encarnadas también en un cierto horizonte testimonial y humanista, pues facilita la lectura y el diálogo con las personas que se colocan frente a la pieza.

Desde esta mirada, la curaduría se podría entender con base en su etimología, curare del latín, cuidar. La pieza no pretende mantener las heridas abiertas o rasgarlas más, pero para que puedan ser curadas, se necesita exponerlas al aire, dejarlas respirar ${ }^{88}$. En este sentido, el artista logra una exposición del caso desde el cuidado. Además, nos comparte sus tejidos más sensibles y busca que los espectadores encuentren ese vínculo y esa experiencia desde su propia corporalidad.

La pieza de Lozano-Hemmer contiene estrategias de resistencia que posibilitan una apertura hermenéutica con información disponible en el dominio público, pues pone mecanismos policiales y de vigilancia al servicio de las víctimas para así, desafiar y resistir la violencia estatal y la tiranía de su "verdad"89. Su pieza, además, exige nuevas prácticas de la mirada: exige volver a mirar, interpretar, verificar y decodificar los mensajes y difundirlos más ampliamente.

La categoría de "archivo" posibilitó la apertura a la forma de aproximación a las obras, pues permitió reevaluar el concepto y poder encontrar esas huellas, no solo en los documentos, también las fotografías. Por su parte, la categoría de "posverdad" permitió situar y localizar los juegos de veracidad con los que el Estado se enfrentó a la sociedad civil, sin exigencias claras por parte de la población. Pero, a la vez, fue importante comprender el proceso del Estado para fabricar pruebas, encubrir, borrar y repetir una "verdad" solo para limpiar su reputación, sin importar los grados de verdad o mentira.

De esta manera, hubo mucha más claridad para comprender las continuidades de la violencia por parte del Estado y del sistema que se adecúa a la borradura. En especial cómo el Estado mexicano no tiene una estrategia clara para la protección de las víctimas en un contexto de "capitalismo gore" que, al dejar a la población sin ninguna protección y al enfrentarse sola frente a la violencia del país, vive la "necropolítica" desde distintos niveles a lo largo del país.

Franco "Bifo" Berardi llama a las formas de resistencia ante el espacio de veridicción impuesto como activismo o artivismo mediático. En él la resistencia no se centra en solo decir la verdad, sino, más bien, en construir escenarios mitológicos capaces de mantener activas las capacidades cognitivas creativas, éticas y estéticas $^{90}$. Desde esta perspectiva, fue importante comprender cómo el arte posibilita nuevas lecturas, amplía la visibilización de este tipo de problemáticas y también permite una mirada que se aleja de la lógica fetichista de la violencia y de "otrorizar" los acontecimientos que suceden en geopolíticas distintas al Primer Mundo.

Considero importante hablar de estos temas, pero también visibilizar las etiquetas con las cuales se mira a las periferias, las fronteras, lo limítrofe y los lugares invisibilizados. Así se podrá comenzar a leer la diversidad de geopolíticas con categorías más enfocadas a las realidades locales, sin olvidar su relación, inevitable, con lo global. No se pretende utilizar las mismas categorías o unas opuestas, más bien poner en

\footnotetext{
${ }^{87}$ Mara Polgovsky Ezcurra et al., Reality Machines: An Art Exhibition on Post-Truth (México: Tecolotl Press, Gato Negro y Cambridge: CRASSH, CLAS, Universidad de Cambridge, 2018), 18.

${ }_{88}$ Aurelio Meza, "Curar saberes difíciles. Arte y curaduría en contextos violentos: el caso Ayotzinapa", Calle 14. Revista de investigación en el campo del arte 12, n. 21 (2017): 29, https://doi.org/10.14483/21450706.11903.

89 Eyal Weizman et al., Forensis, 11.

90 Citado en Marzo, "Exhumar la verdad", 24.
} 
crisis los modos epistémicos de construir la realidad actual que sesga las relaciones a partir de las ideologías racistas, machistas o esencialistas. El arte es un lugar también limítrofe y fronterizo que trastoca lugares epistémicos distintos y diversos y que puede llegar a posibilitar esta apertura hermenéutica que tanto se necesita.

ISIS MARIANA YÉPEZ ROGRÍGUEZ es graduada en Pedagogía por la Universidad Nacional Autónoma de México (UNAM) y técnica en Museografía y restauración por la UNAM, habiendo realizado prácticas en el Museo Frida Kahlo de la Ciudad de México. Obtuvo el Máster en Historia del Arte Contemporáneo y Cultura Visual por la Universidad Autónoma de Madrid (UAM).

Realizó prácticas profesionales de grado como asistente editorial en el Instituto de Investigaciones Estéticas sobre la Universidad y la Educación (IISUE) (octubre 2012 - julio 2013). Trabajó en Programas Públicos del Museo Universitario de Arte Contemporáneo de la Ciudad de México (MUAC) (enero 2013 - julio 2014) y realizó prácticas extracurriculares de Máster en IvoryPress, Madrid (noviembre 2018 - febrero 2019). Ha formado parte del equipo curatorial de la exposición de Modernidades extraviadas. Bauhaus y España en el Museo Nacional Centro de Arte Reina Sofía (MNCARS).

Ha publicado artículos en Cultura Colectiva "El artista de lo inmaterial y efímero: Tino Sehgal" (2016); en la revista Acta, "La teatralidad de la imagen: tortura y resistencia" (2018) y en la revista Capitel: "La voluntad del deseo, cuerpo afectividad y pedagogía" (2018), "Pedagogías nómadas y la fuerza del caminar" (2019) y "El silencio como performance" (2020).

Email: isismyr@gmail.com

Código ORCID: https://orcid.org/0000-0001-8507-5789 